\title{
新疆における農村の都市化と経済発展
}

\author{
居来提熱依木（神戸大学大学院・新疆大学） \\ 草苅仁（神戸大学農学研究科）
}

\section{Rural Urbanization and Economic Development in Xinjiang, China}

\author{
Julaiti Reyimu (Graduate School of Kobe University/Xinjiang University) \\ Hitoshi Kusakari (Agricultural Science of Kobe University)
}

The Xinjiang Uyghur Autonomous Region, located in western China, faces the problems of rural surplus made efforts to resolve these problems by promoting the growth of secondary and tertiary industries in the region.

The purpose of this is to confirm whether this promotion by the government has helped rectify problems relating to excess labor and agricultural

\section{1. はじめに}

中国では，東部の都市地域に抢訬る急速な経済発 展の一方で, 西部の農村地域では農家の生活水準が 相対的に低下寸るなど，都市部と農村部との格差が 深刻化している。国政府は農村部に扮ける農家所 得の向上に強い関心を払ってきたにもかかわらず， 地域間の発展が不均衡となり, 都市部と農村部, あ るいは東部と西部で所得格差が拡大している。こう した所得格差を縮小寸ることが，現代の中国にとっ て重要な政策課題である. そのため, 農業から第二 次産業や第三次産業への労働移動が不可欠であると 考光ら机る。

新疆ウイグル自治区（以下，新疆）は中国の西部 飞位置して打り, 経済発展は他省と比較して遅滞し ている。緩慢な経済発展のもとで, 農村部の過剩な 労働力と資金不足といら問題に直面してきた。 その ため, 労働生産性が低く, 低収入な伝統的農業が経 済活動の中心であり, 閉塞的な経済状沉が東部や中 部との格差を拡大させたと考兄られる。これに対し て, 中国政府は新疆を西部大開発の重点地区と位置 づけ，大規模な投資や様々な優遇政策を実施した． このよらな施策を通じて, 農村に滞留する過剩労働 力を他産業に移動させ, 農業の労働生産性向上と, productivity in Xinjiang; it does so by estimating changes in the share of labor in agriculture in 19802010. The estimation results show that agriculture's share of the overall labor force increased from $11.9 \%$ in $1980-1999$ to $19.2 \%$ in $2000-2010$ and it was found that the government' $s$ promotion helped increase farmers' incomes after 2000.

第二次・第三次産業の成長を目指した，新疆政府は， 「新疆城鎮体系計画（2012～2030 年)」の審議稿に特 いて，都市部の人口比率を，2015 年末までに人口全 体の $48 \%$ 前後， 2020 年末までに $58 \%$ 前後，2030 年 末までに 66 ～68\%（都市人口を 2000 万人）に，そ れぞれ増加させることを目標としている。

これまで, 新疆農村の都市化に関しては, 張 (2001) が, 農村工業発展の受け㿼であり, 農業労働力の移 動において重大な役割を果たす小城鎮建設の重要性 を指摘している. 小城鎮建設を可能にするためには, 農産物の加工・転化・貯蔵・運輸・販売なぞ広い範 囲の郷鎮企業が集中し，余剩労㗢力を吸収する能力 があることが必要である。この点関して，吾買尔 江（2005）は，実証分析によって，郷鎮企業が比較 的高い雇用吸収力を持つことを明らかにした。 しか し, 彼らの先行研究では, 農業労働力の都市への移 動が農業所得の向上に貢献できるかぞらかに関する 分析が見られない，そのため，本稿では，1980 年 以降，都市化率の上昇が見られる新疆に扔いて，農 業労働力の都市への移動が農業の過剩就業を改善し て，農業所得の向上に寄与しているかどらか実証的 に明らかにすることを課題とする。 


\section{2. 新疆における都市化の現状}

1978 年の改革開放以来, 30 数年が経過したが, 農業の生産性は工業の生産性よりも低く, 農民の所 得向上のためには, 農業労㗢力の他産業への移動が 欠かせない状沉である，そのため，政府は郷鎮企業 が集中している地域に多数の小城鎮を建設して，過 剩労働力を農村地域内で「吸収する」政策を打ち出 した.こうした中で, 新疆政府も小城鎮の建設には よる農村の都市化を推進してきた。

新疆では, 1978 年には 1,233 万人の総人口に対し て城鎮人口が 321 万人であり，この割合を示す都市 化率 ${ }^{1)}$ は2 $6.1 \%$ であった（14市，72 県)。それから 約 30 年が経過した 2010 年には，2,181 万人の総人 口に対して城鎮人口は 891.29 万人となり, 都市化 率は 40.9\%まで上昇した（21 市，68 県，234 鎮). 都市化によって郷鎮企業及び竜頭企業も増加し, 2008 年までに, 全自治区で郷鎮企業数が 378,343 社 に, その中農産品加工企業数が 5,168 社に, 三級（国 家, 自治区, 地州市) 農業産業化重点竜頭企業数が 400 社に, 一般竜頭企業数が 155 社に達し, 従業者 数が $1,063,023$ 人となり, 産業別就業者比率も変化 した. 図 1 に示すと打り, 1978 年には $72.2 \%$ を占 めた第一次産業就業者は, 2009 年には 49.3\% に減 少した。これにより，第三次産業の就業者比率が一 貫して上昇した一方で，第二次産業では $10 \%$ 台で 推移している。 また，産業別の GDP 構成比を図 2 で確認すると, 1980 年代前半から, 全産業に占め る第一次産業の GDP 割合は低下傾向にあり, 逆に 2000 年代初頭まで，第三次産業の GDP 割合が上昇 していたことがわかる.

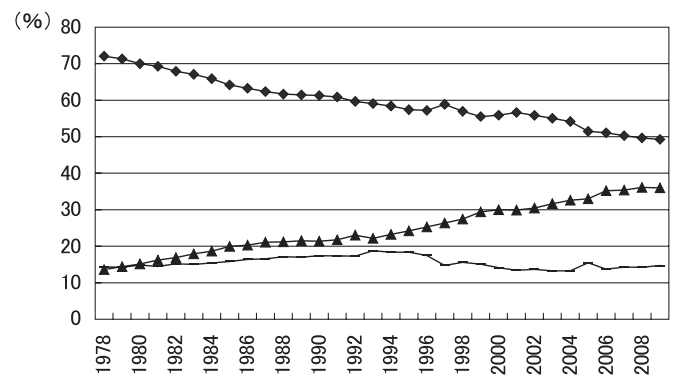

図 1. 産業別就業者数構成比

出所：『新疆統計年鑑』各年版より作成
(\%) 60

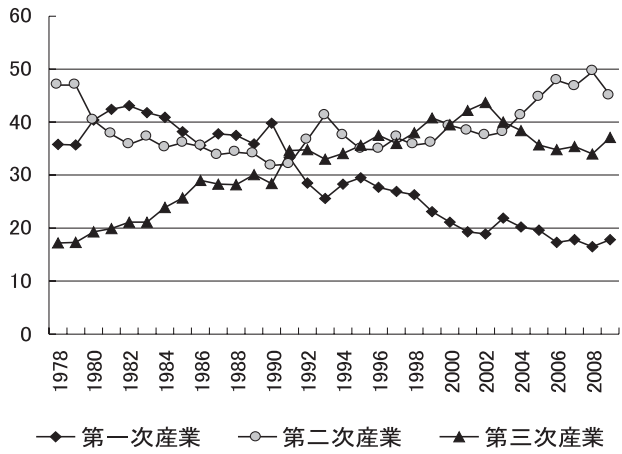

図 2. 産業別 GDP 構成比

出所：『新疆統計年鑑』2010 年版より作成

\section{3. 分析の枠組み}

新疆農村の都市化，すなわち農業労働力の城鎮へ の移動が農業部門の過剩就業の改善に寄与している かぞうか実証するため，農業の労働分配率を計測す る. そのため, (1) 式のよらに, 農業の生産関数を コブ・ダグラス型で定式化する.

$$
Y=A X_{1}^{\beta_{1}} X_{2}^{\beta_{2}} X_{3}^{\beta_{3}} X_{4}^{\beta_{4}} X_{5}^{\beta_{5}}
$$

ここで, 被説明変数 $(Y)$ は農業総生産額であり, 2005 年の価格で実質化している. 説明変数 $(X)$ は 資本，労働，土地，経常財の投入である。 それぞれ， 農村への固定資産投資額（2005 年の価格で実質化. $\left.X_{1}\right)$, 農業従事者数 $\left(X_{2}\right)$, 作付面積 $\left(X_{3}\right)$, 農業用 肥料使用量 $\left(X_{4}\right)$ を用いる ${ }^{2)}$. また, 技術進歩の代 理変数 $\left(X_{5}\right)$ としてタイム・トレンドを加える. 定 数項 $A$ と $\beta_{1}, \beta_{2}, \ldots, \beta_{5}$ は回帰係数である.

(1) 式の両辺について自然対数を取る（logeを ln で略記する）と（2）式となる.

$$
\begin{aligned}
\ln Y= & \beta_{0}+\beta_{1} \ln X_{1}+\beta_{2} \ln X_{2} \\
& +\beta_{3} \ln X_{3}+\beta_{4} \ln X_{4}+\beta_{5} \ln X_{5}
\end{aligned}
$$

ただし， $\beta_{0}=\ln A$ である。

計測期間の $1980 \sim 2010$ 年の 31 年間については, 扣打よそ 10 年ごとに大きな政策的な変更があった。 80 年代初期には「改革開放」政策によって「家庭 連産責任制」が実施された. 90 年代に入って計画 経済から市場経済に転換し，郷鎮企業の発展と農村 の過剩労働力の他産業への移動が政策的に重視され るよらになった。 2000 年以降，「社会主義新農村」 建設による中国全土に打浽農業構造の調整の強 化，西部大開発戦略による新疆の経済開発，WTO 
加盟が行われた。そのため，1980 年代から現在ま での農村から都市への労働力の移動が農業の労働分 配率をどのよらに変化させたかを明らかにするた め， 80 年代， 90 年代， 2000 年代を識別する期間ダ ミーを（2）式に付加し，（3）式を得る.

$$
\begin{gathered}
\ln Y=\beta_{0}+\beta_{1} \ln X_{1}+\left(\beta_{2}+\gamma_{1} d_{u m}+\gamma_{2} d_{u m}\right) \ln X_{2} \\
+\beta_{3} \ln X_{3}+\beta_{4} \ln X_{4}+\beta_{5} \ln X_{5}
\end{gathered}
$$

ただし，dum は $1990 １ 999$ 年で $1 ， 1980 １ 989$ と $2000 ２ 010$ 年で 0 であり, dum 2 は $2000 \sim 2010$ 年で $1,1980 \sim 1999$ 年で 0 である. 計測データは『新 疆統計年鑑』による $1980 ２ 010$ 年の時系列データ である。

\section{4. 計測推定と考察}

回帰分析に先だって, 説明変数間の多重共線関係 を回避するため, はじめに $X_{1} \sim X_{4}$ について主成分 分析による相互に無相関な合成変数を作成し, こ水 を新たな説明変数として回帰分析を行う ${ }^{32}$.

表 1 亿主成分分析の結果を示すが，標本妥当性の 測度である $\mathrm{KMO}$ は 0.707 であり，主成分分析とし て妥当な結果が得られた ${ }^{4)}$. 第一主成分と第二主成 分の累積寄与率は $95.3 \%$ となり，第二主成分までで ほぼすべての情報を回帰式に反映することが可能で あると判断される. 以上から, 表 2 に示す構造係数 と固有ベクトルを算出した結果, 第一主成分 $\left(Z_{1}\right)$ と第二主成分 $\left(\boldsymbol{Z}_{2}\right)$ は，（4）式と（5）式示すと 打りとなった。

次に, $Z_{1}, Z_{2}$ と $\ln X_{5}$ を説明変数とする回帰分析 を行った結果, (6) 式に示す回帰係数が得られた. (6) 式のカッコ内の数字は回帰係数の $t$ 值であり, 計測 に用いたサンプル数は 31 である. 統計量は, 決定 係数が $0.992, F$ 值が 1190.9, ダービン・ワトソン

表 1. 主成分の固有値と寄与率

\begin{tabular}{c|c|c|c}
\hline \hline \multirow{2}{*}{ 成分 } & \multicolumn{3}{|c}{ 固有值 } \\
\cline { 2 - 4 } & 合計 & 寄与率 $(\%)$ & 累積寄与率 $(\%)$ \\
\hline 第1 成分 & 4.379 & 72.987 & 72.987 \\
第 2 成分 & 1.336 & 22.273 & 95.260 \\
第 3 成分 & 0.176 & 2.938 & 98.198 \\
第 4 成分 & 0.054 & 0.908 & 99.106 \\
第5 成分 & 0.051 & 0.857 & 99.963 \\
第6 成分 & 0.002 & 0.037 & 100.000 \\
\hline \multicolumn{3}{|c}{}
\end{tabular}

表 2. 構造係数と固有ベクトル

\begin{tabular}{c|c|c|c|c}
\hline \hline \multirow{2}{*}{} & \multicolumn{2}{|c|}{ 構造係数 } & \multicolumn{2}{c}{ 固有ベクトル } \\
\cline { 2 - 5 } & 第 1 成分 & 第 2 成分 & 第 1 成分 & 第 2 成分 \\
\hline $\ln X_{1}$ & 0.970 & 0.184 & 0.464 & 0.159 \\
$\ln X_{2}$ & 0.945 & 0.214 & 0.452 & 0.185 \\
$d u m_{1} \ln X_{2}$ & -0.136 & 0.984 & -0.065 & 0.851 \\
$d u m_{2} \ln X_{2}$ & 0.870 & -0.420 & 0.416 & -0.363 \\
$\ln X_{3}$ & 0.938 & -0.166 & 0.448 & -0.144 \\
$\ln X_{4}$ & 0.944 & 0.291 & 0.451 & 0.252 \\
\hline
\end{tabular}

比が 0.774 であった. 回帰係数の $t$ 值と回帰式

$$
\begin{aligned}
Z_{1}=0.464 \cdot \ln X_{1}+0.452 \cdot \ln X_{2} \\
-0.065 \cdot d u m_{1} \cdot \ln X_{2}+0.416 \cdot d u m_{2} \cdot \ln X_{2} \\
\quad+0.448 \cdot \ln X_{3}+0.451 \cdot \ln X_{4}
\end{aligned}
$$

$$
\begin{aligned}
& Z_{2}=0.159 \cdot \ln X_{1}+0.185 \cdot \ln X_{2} \\
& +0.851 \cdot \text { dum }_{1} \cdot \ln X_{2}-0.363 \cdot \text { dum }_{2} \cdot \ln X_{2} \\
& -0.144 \cdot \ln X_{3}+0.252 \cdot \ln X_{4}
\end{aligned}
$$

$$
\begin{aligned}
& (81.225)(16.590) \\
& +0.067 Z_{2}+0.178 \ln X_{5} \\
& (10.463) \quad(5.057)
\end{aligned}
$$

の $F$ 值は，計測結果が $1 \%$ 水準で有意であることを 示しているが，ダービン・ワトソン比は系列相関の 可能性を示唆している。

系列相関の可能性を留保しながら，以上の結果か ら，（4）式と（5）式を（6）式に代入することで, 新疆の農業生産関数として（7）式が得られる.

$$
\begin{aligned}
& \ln Y=11.035+0.120 \ln X_{1}+(0.119 \\
& \quad(81.225) \quad(7.822) \quad(7.529) \\
& \left.+0.042 \cdot d_{u m}+0.073 \cdot \text { dum }_{2}\right) \ln X_{2} \\
& \quad(0.969) \quad(3.341) \\
& +0.096 \cdot \ln X_{3}+0.123 \cdot \ln X_{4}+0.178 \cdot \ln X_{5} \\
& \quad(6.592) \quad(6.825)
\end{aligned}
$$

（7）式のカッユ内の数值は回帰係数の $\mathrm{t}$ 值である 5). 計測結果はX2 の dum 1 を除いて $1 \%$ 水準でゼ 口と有意差を持つ。

（7）式の計測結果は, 各説明変数の生産弾力性推 計伹はすべて正であり，理論的に要請される符号条 件を満たしている。このうち労働 (X2) については, 90 年代ダミー (dum1) がゼロと有意差を持たなかっ たため, 労働の生産弾力性は 80 年代から 90 年代に 
かけて統計的に変化しなかったと判断される.一方, 2000 年代ダミー (dum2) は有意であり，この間の 生産弾力性の変化は, 90 年代に $11.9 \%$ であった労 働分配率が，2000 年代に 19.2\%まで増加したこと を示している，以上の結果より，新疆に抢ける農村 の都市化政策は，農業に打ける過剩就業の改善策と して，2000 年代以降に効果を発揮し，その結果， 農業の労働分配率は $11.9 \%$ から 19.2\%へ，7.3\%上 昇したことが明らかになった 6). その一方で，技 術進歩を除く慣行的投入要素（X1～X4）の生産弾 力性合計值は, 2000 年代でも 0.531 と依然として小 さく, 特に土地生産性の低い粗放的農業がその背景 にあることを計測結果は示している。

\section{5. 結論}

本稿では, 1980 年以降, 都市化率の上昇が見ら れる新疆において, 農業労㗢力の都市への移動が農 業の過剩就業を改善して, 農業所得の向上に寄与し ているかどらか実証的に明らかにすることを課題と した，そのため，農業の労働分配率が時系列的にど のように変化したかについて実証分析を行った。農 業生産関数の農業従事者数 $\left(X_{2}\right)$ に 10 年ごとの期間 ダミーを付加して計測した結果, 労衝分配率は 1980 〜 99 年の $11.9 \%$ から，2000～2010 年の 19.2\%ま で上昇したことが明らかになった。新疆において， 農業の過剩就業改善策は，2000 年代以降，農民の 所得向上に効果をもたらしたことが実証的に確認さ れた。

ただし，生産関数の計測結果は，新疆の農業が規 模に関して収穫が逓減する状沉にあり，それが主に 土地生産性の低さに起因していることを示唆してい る. したがって, 農業所得をさらに増加させて産業 間の均衡的発展を目指すためには，産業間の労働移 動と同時飞，農業に扔ける土地生産性の向上を目指 寸施策も必要であると考兄られる。

な拈，農業生産関数の計測に際して，多重共線性 による推計バイアスを回避するため，主成分分析を 援用した，データの制約から，農業の資本投入を農 村の資本投入 $\left(X_{1}\right)$ で代理せざるを得なかった点， ならびに（6）式の計測結果が系列相関を示唆して いる点の改善は, 残された課題である.
注 1）都市化率は，総人口（城鎮人口と郷村人口の合計） に占める城鎮人口の割合である.

2）沈 [3], 白砂 [4] を参照.

3）白砂 [5], 王 [7], 張 [8] を参照.

4）標本妥当性の測度 KMO（Kaiser-Meyer-Olkin）は, 因子分析の適用を決めるための測度であり，0.6 以 上が許容される範囲である. Kaiser and Rice(1974)

２］を参照. 主成分分析にはSPSS 17.0 を用いた.

5）（7）式に扣いて, $\beta 1 \sim \beta 4, \gamma 1, \gamma 2$ の t 值の算出方法 は, Gunst and Mason［1] を参照.

6）農業の労働分配率について，3 期間に打ける経年 変化を統計的に検証することが計測式の目的であ り, 農業の構造変化を定義・検証するものではない，

\section{参考文献}

[1] Gunst, R. F. and R. L. Mason, Regression Analysis and Its Application, New York: M. Dekker, 1980.

[2] Kaiser, H. F. and J. Rice (1974) "Little Jiffy Mark IV”, Educational and Psychological Measurement, 34 (Spring). pp. 111-117.

[3] 沈金虎『現代中国農業経済論』,農林統計協会, 2007 年.

４4］白砂堤津耶『中国農業の計量経済分析』，大明 堂, 1986 年.

[5]白砂堤津耶『例題で学ぶ初歩からの計量経済 学』, 日本評論社, 2007 年.

[6]王燕杰「我国経済成長多因素模型実証研究一 基于主成分回帰分析」、『長春大学学報』第 20 卷第 1 期, 2010 年, pp. 17-20.

[7]吾買尔江艾山「新疆ウイグル自治区郷鎮企業 の雇用吸収力に関する実証分析」、経済論叢』 （京都大学）第 176 巻第 4 号, 2005 年, pp. 41-65.

[8] 張斌「基於主成分回帰分析的新疆農業経済成 長影響因素評価」,『新疆財経大学学報』第 4 期, 2008 年, pp. 29-31.

[9] 張建江「新疆農業和農村経済構造調整思考」 陸宗義・李周為主編『西部大開発和新疆経済 発展戦略』新疆人民出版社， 2001 年，pp. 360-367.

（受理日：2013 年 3 月 11 日） 